\title{
When protectors become predators: A penal policy ap- proach to ending the impunity of UN peacekeepers com- mitting sexual exploitation and abuse in the host states
}

\author{
M Rafiqul Islam ${ }^{1 *}$, Tareq Al-Fahdawi ${ }^{2}$ \\ 1, 2 Macquarie University, Sydney, Australia
}

\author{
Keywords \\ UN \\ Peacekeepers \\ Sexual exploitation \\ Abuse \\ Immunity \\ Secretary-general \\ Received: 02 January 2021 \\ Accepted: 13 April 2021 \\ Published: 28 June 2021
}

\begin{abstract}
For decades, the UN peacekeeping operations in poverty-stricken, war-torn host states have been littered with instances of the commission of Sexual Exploitation and Abuse (SEA) of vulnerable women by peacekeepers. The governing system of the UN peacekeeping missions has been adopting successive measures to prevent peacekeepers from committing SEA with limited success. Preying on these defenseless women by peacekeepers, who are mandated to protect the civilians in host states, is a heinous crime prohibited under national and international criminal laws. This article examines the insular law governing the UN peacekeeping missions to determine how and why the offending peacekeepers escape accountability. Its findings reveal that the UN aggressive measures are riddled with gaps and not proportional to the gravity of the crime, providing no effective deterrent. The unassailable immunity of peacekeepers in host states is a far-fetched notion when they commit such hardcore actionable crimes giving rise to the criminal responsibility of the offending peacekeepers whose prosecution is in order and imperative in the interest of crime prevention and criminal justice. Based on this finding, the article recommends a disciplinary policy approach as a viable alternative legal avenue to end the immunity and impunity of the offending peacekeepers. The implications of such a corrective penal step would create a legal accountability regime to combat peacekeepers' predatory behavior. The novelty of this article lies in its contribution to the existing UN peacekeeping paradigm by providing a searching reappraisal of the immunity of peacekeepers to convey a message across that immunity in contemporary context no longer exonerates from criminal responsibility and hence does not protect and condone UN peacekeepers committing SEA. Implementing a 'hard' punitive penal sanction to mounting incidents of peacekeepers' SEA prescribed in this article is of paramount importance for the credible management of the UN peacekeeping missions.
\end{abstract}

\section{INTRODUCTION}

A video clip shared worldwide in the media on June 26, 2020, showed a man and woman engaging in a sexual act at the backseat of a UN vehicle in Israel. The UN spokesperson expressed that the UN is "deeply disturbed" and "appropriate action will be taken". This is not the first time the world has witnessed such sexual misconduct by UN peacekeepers deployed in peacekeeping missions. The history of UN peacekeeping missions is littered with numerous SEA. The SEA committed by peacekeepers against vulnerable women and girls in host states has continued unabated (OIOS, 2005). Without tracing the history of SEA dat- ing back to the 1960s (Thakur, Aoi, \& De Coning, 2007; Murphy, 2006; Human Right Watch, 2016), some recent high incidents of SEA occurred in the Democratic Republic of the Congo (DRC) since 2010, Haiti in 2004-17, Central African Republic (CAR) in 2014, South Sudan in 2018, and Israel in June 2020. In 2017 and the first half of 2018, there were 156 reported cases of SEA, including child victims in 46 cases (Wheeler, 2020; UN Field Mission Conduct, 2020).

The commission of SEA and perpetrators go unpunished under their immunity from the jurisdiction of host states. The UN sanctions against the offending peacekeepers so far are limited merely to strip their positions and repatriate them

\footnotetext{
*corresponding author: M Rafiqul Islam

†email: rafiqul.islam@mq.edu.au
} 
to their home states for investigations and punishments under a Memorandum of Understanding (MOU) 2007. Troops contributing home states usually are reluctant to investigate seriously, and many substantiated allegations remain in limbo for want of prosecution. As a result, the impunity of perpetrators persists. The UN is aware of the problem and conducted multiple investigations by its Office of Internal Oversight Services and adopted various combating measures, including the zero-tolerance policy in 2003 and Zeid Report in 2005, yielding only limited results.

The legal system governing the UN peacekeeping missions suffers from certain gaps through which the perpetrators escape accountability. These gaps must be addressed for any preventive action to be effective. Preying on defenseless women at risk in poverty-stricken and war-torn host states by peacekeepers mandated to protect these civilians is a heinous crime prohibited under national and international criminal law. This article (a) examines the legal system surrounding UN peacekeeping operations to identify the caveats, and (b) suggests legal avenues to create an accountability regime that makes SEA actionable and their perpetrators culpable in law so that these sexual predators can be brought to justice with punitive sanctions. It is the immunity of peacekeepers in host states that remains the root cause of impunity. The article shows legal alternatives under which the exemption can be waived to attribute criminal responsibility to the offending peacekeepers to face criminal justice.

\section{RESEARCH METHODOLOGY}

This research has been undertaken by employing the doctrinal analysis method, a traditional method of legal research. This method affords an internal, participant-oriented epistemological approach to its object of study by applying the pertinent legal rules in each fact to provide a complete statement of law. Resort to this method provides a systematic exposition of all legal concepts and principles relevant to a particular topic. For this study, this method has identified legal issues involved, critically analyzed the UN laws and practice governing its peacekeeping operations, and demonstrated the nexus between the UN law and the offending peacekeepers escaping accountability through the gaps in that law. This inadequacy of the UN law has led to a reformist pursuit necessary to make it effective for combating SEA committed by peacekeepers. To facilitate legal analysis on this reformative approach, this research has examined relevant primary sources such as the UN reports and secondary materials, including books, journal articles, case studies, internet sites, and NGO reports.

\section{Mandates of UN Peacekeepers}

The success of any UN peacekeeping mission depends on its mandate devised by the Security Council. These mandates differ from mission to mission based on the requirements of host states and mission goals. Nonetheless, an appointment common in all missions is to protect civilians and prevent any violation of human rights. The most comprehensive review of these mandates is the Brahimi Report adopted by the General Assembly and Security Council on 21 August 2000 (United Nations, 2000). Since this report, the UN has launched 20 peacekeeping missions (United Nations, 2017). Although the UN has adopted the mandate to use force to protect civilians since the Brahimi Report, UN peacekeeping operations continue to have problems with protecting civilians, particularly stopping SEA (Willmot \& Sheeran, 2013). The civilians continue to suffer grave human rights abuses in most host states by both rival armed groups and peacekeepers.

The peacekeeping missions in Chad, CAR, and South Sudan were launched well after the Brahimi Report. The common mandate on these missions was to protect civilians from the atrocities of armed groups and any other attacks in eastern Chad, north-eastern CAR, and western Sudan. The operations in these states have legitimate purposes of restoring stability and avoiding serious violations of human rights and International Humanitarian Law (IHL). Peacekeepers had sufficient mandates to protect civilians, which led the Security Council to assert that these operations would succeed. The success of these missions was predicated on the mandates increasing the ability of peacekeepers to use force to protect civilians and prevent abuses of human rights and IHL. However, the criminal activities of insurgent groups continued to "primarily affect civilian population and humanitarian efforts" in addition to SEA by peacekeepers.

An examination of the Brahimi Report reveals that the protection of civilians is not explicitly mentioned in the report. As a result, the obligations of peacekeepers to prevent the crimes of insurgent groups in host states have remained ambiguous, a gap that keeps the door open for peacekeepers to exploit their position to commit SEA against civilians with impunity. It has failed to prescribe an accountability mechanism for the offending peacekeepers. The effects of this failure are evident in the fact that there has been no reform thus far requiring missions to ensure the full protection of civilians in host states (Wills, 2009). There have been 144 allegations raised in different UN peacekeeping operations in 2016-17, evidencing many sexual tragedies experienced by civilian women in host states (UN Field Mission Conduct, 2020). The CAR mission mandate was meant to pro- 
tect human rights and IHL, and the Security Council placed the protection of civilians as one of the top priorities for the mission. Yet Human Rights Watch (HRW) reported numerous crimes committed by insurgents until 2015 using special fighting tactics that resulted in the killing of civilians, razing of villages, and forcing tens of thousands of people from their homes and into the bush, where hundreds died for want of adequate protection from peacekeepers who did not use force to prevent such attacks despite the authorization to do so by the Brahimi Report (Human Right Watch, 2017).

The legal system governing the UN peacekeeping missions still requires reforms to improve the protection of civilians and prevent SEA by peacekeepers and armed groups in host states. There was also no framework on how the offenders could be prosecuted. These gaps seemingly incentivize peacekeepers to ignore their mandated responsibility and turn from protectors to sexual predators. This is largely attributable to the exclusion of criminalization of SEA and prosecution in host states due to the immunity of peacekeepers, which is conveniently exploited for impunity. Peacekeepers are aware that host states cannot prosecute them for their SEA because of their immunity from the local jurisdiction, and in the worst scenario, they will be stripped from their commission and sent back to their home states. The Brahimi Report has had only a limited impact on UN peacekeeping operations, and the protection of civilians remains a challenge. Its non-explicit criminalization of peacekeepers and the jurisdictional gap have led peacekeepers to exploit the need of impoverished civilians to violate them sexually.

\section{Obligations of Peacekeepers Under International Hu- man Rights and Humanitarian Laws}

The protection of human rights recognized in international law is an obligation that cannot be ignored during UN peacekeeping missions. Too many international and regional human rights instruments have emphasized that human rights are for everyone without any distinction. The International Covenant on Civil and Political Rights protects all-time and everywhere during peace and war regardless of whether the war is international or non-international (Heintze, 2011; Maus, 2011). The European Convention on Human Rights confirms the non-derogability of human rights during the time of war (Article 15).

There exists a substantial jurisprudential and judicial authorities maintaining that a state may be held accountable for gross violations of human rights by their nationals, even private if that state tolerates them or provides them with protection in law (LCB v UK. Application/Case no. 14/1997/798/100, 1998; Mahmut Kaya v Turkey. Application/Case no. 22535/93, 2000; Osman v UK. Application/Case no. 23452/94, European Court of Human Rights, Judgment of October 28, 1998). Despite this legal obligation of states, civilians continue to face serious protection challenges and suffer from gross violations of human rights, including SEA by some peacekeepers. These allegations have been recorded mostly from DRC, CAR, Bosnia and Herzegovina, Cambodia, East Timor, Haiti, Sierra Leone, Liberia, South Sudan, and Israel. The victims in these allegations are both adults and children. The problem of committing SEA during the UN peacekeeping missions is not limited to physical and emotional torments of the direct victims only, and it also has severe consequences on their fundamental human rights. In Haiti, the UN worked hard to enable the children born from SEA by peacekeepers to get their education by going to school and the victim women to be rehabilitated in the community (UN Field Mission Conduct, 2020). The four Geneva Conventions 1949 and their two Additional Protocols 1977 prescribe IHL rules. These rules protect civilians, and anyone no longer taking part in armed conflict and prevent all misconduct, including SEA, against civilians. IHL includes conventions and treaties that protect civilians during armed conflicts. Because of the deployment of peacekeeping forces in unstable states for post-conflict peace restoration, the application of IHL is very important to reduce or prevent harm to civilians. This explains why the Geneva Convention IV criminalizes SEA explicitly, and any violence against women or children is prohibited, including the crimes against "their honor, in particular against rape, enforced prostitution, or any form of indecent assault" (Article 27). Despite this civilian protection regime in IHL and peacekeepers' positive obligations to protect civilians, the suffering of civilians in host states in the hands of some peacekeepers and/or insurgents is yet to be dissipated.

Peacekeepers, particularly in CAR, used their position to commit SEA against several women and young children in exchange for food or money (Al-Jazeera, 2016). The human dignity of these victims was violated and their honor by their so-called protector with absolute impunity. These perpetrators escaped accountability because "information about the allegations was passed from desk to desk, inboxto-inbox, across multiple UN offices, with no one willing to take responsibility to address the serious human rights violations" (Deschamps, Jallow, \& Sooka, 2015). These incidents of SEA are clear violations of peacekeepers' obligations under international human rights and humanitarian laws and in total defiance of the UN's "zero-tolerance pol- 
icy" (United Nations, 1999).

The mandate for peacekeepers in DRC has specifically mentioned that peacekeeping forces are responsible for providing "protection of civilians from violations of IHL and human rights abuses, including all forms of sexual and genderbased violence". Common Article 1 of the Geneva Conventions places a definite obligation on the High Contracting Parties to "respect and ensure respect" for the Conventions "in all circumstances." The ICJ reaffirms this obligation in the Nicaragua case:

That there is an obligation on the United States Government, in terms of Article 1 of the Geneva Conventions, to "respect" the Conventions and even "to ensure respect" for them "in al1 circumstances", since such an obligation does not derive only from the Conventions themselves, but from the general principles of humanitarian law to which the Conventions merely give specific expression. The United States is thus under an obligation not to encourage persons or groups engaged in the conflict in Nicaragua to act in violation of the provisions of Article 3 common to the four 1949 Geneva Conventions (Burke, 2014; Nicaragua v US. Military and Paramilitary Activities in and Against Nicaragua, 1986; UK v Albania. Corfu Channel Case, International Court of Justice Reports, 1949).

The Secretary-General's Bulletin in 1999 maintained that "the fundamental principles and rules of IHL set out in the present bulletin apply to the UN peacekeeping forces when in situations of armed conflict, they are actively engaged therein as combatants" (United Nations, 1999). In 2009, the UN Legal Counsel opined that the Organisation had strict obligations under customary international law and the Charter to uphold and respect human rights and IHL. This obligation was expressly recognized in the UN Human Rights Due Diligence Policy endorsed by the Security Council in 2013. Hence, the applicability of customary and conventional international law on international organizations is well-established.

The UN Secretary-General António Guterres has vowed to end the continuing SEA by "outlining a new victim-centered approach to prevent and respond to such abuses committed by those serving under the UN flag". In defiance of this specific obligation, peacekeepers failed to protect the human rights of women and girls to their physical integrity and security from attacks by local armed groups, but also some peacekeepers themselves committed SEA in mission states. Allegations against some peacekeeping missions include failure to take sex crimes seriously, investigate fully, report to the UN, and even complicity in these violations (Amnesty International, 2011; Alston, 2009; OIOS, 2014).

\section{UN Measures to Combat SEA by Peacekeepers}

In the face of mounting allegations against peacekeepers committing serious sexual crimes and/or failing in their duty to protect civilians in host states, the UN took several steps, which achieved limited success and proved to be too lackluster to be preventive.

\section{The Zero-tolerance Policy}

The UN Secretary-General in 2003 adopted a three-pronged special measure of prevention, enforcement, and remedial action to combat SEA. He issued a "zero-tolerance policy" by introducing mandatory measures prohibiting all forms of sexual misconduct against women, girls, underaged, and beneficiaries of assistance by UN personnel of all peacekeeping missions (sections 2(2)). His Bulletin containing these special measures classifies "sexual exploitation" and "sexual abuse" as two separate crimes and criminalizes and prohibits any sexual activity regardless of whether there is consent from the victims and their age or gender (UN General Assembly, 2002).

The enforcement of the "zero-tolerance policy" encountered difficulties owing to wide discrepancies in sanctions. The civilian personnel guilty of substantiated SEA were mostly removed from service. The disciplinary sanctions against the offending military and police personnel were mostly repatriation and bans on their recruitment in future peacekeeping operations. Very few offending peacekeepers faced a jail terms of usually confidential duration. Contingent or mission commanders had hardly any accountability for SEA commission by themselves or their failure to discipline the offending peacekeepers under their effective control or report these incidents to the UN in defiance of their command responsibility (section 4). Despite an absolute injunction on transactional sexual acts in exchange for money and relief foods or goods (section 2.2(c)), these acts were rampant in the DRC and CAR peacekeeping missions, which was largely ignored or grossly underreported by the mission commanders disregarding their reporting obligations (section 2.2 (e)). The "zero-tolerance policy" did not overtly ban, only discouraged, sexual relations between UN staff and beneficiaries of relief assistance despite its "inherently unequal power dynamics" (section 2.2(d)). The lackluster remedial actions suffered from inadequate funds released slowly through a lengthy process by inefficient bureaucratic machinery. Consequently, many victims felt betrayed by the lack of proper and effective remedial assistance services promised in the Secretary-General's Bulletin (OIOS, 2015).

The "zero-tolerance policy" was the first serious institu- 
tional response of the UN. This was followed by the Zeid Report 2005 prescribing measures to prevent SEA, which too has not ameliorated the suffering of civilians as SEA by peacekeepers continue to occur in most host states with impunity. Its failure is evident in the statement of SecretaryGeneral Kofi Annan in December 2006: "My message of zero-tolerance has still not got through to all those who need to hear it - from managers and commanders on the ground, to all our other personnel". Even after this warning, the allegations of SEA increased in Sudan as reported in January 2007, which took a turn for the worst by rampant systematic rape and abuse of children as young as twelve (Holt \& Hughes., 2007; Jerusalem Post, 2007).

In February 2017, the Secretary-General adopted yet another new strategy to improve the protection of civilians and prevent SEA. This strategy focused on four actions: (1) putting the victims first, (2) ending impunity, (3) engaging civil society and external partners, and (4) improving strategic communications for education and transparency. These measures, like all other past steps, did not stop SEA or end impunity. In February 2020, the Secretary-General updated his strategy, including prioritizing accountability throughout the UN system (Special Measures, 2020). However, the UN statistics as recent as in 2019 and 2020 have identified 132 victims from 121 allegations raised against UN peacekeepers for committing SEA in host states (UN Field Mission Conduct, 2020). These allegations highlight an institutional failure in the UN peacekeeping missions. The lackluster accountability mechanism of the UN encourages its peacekeepers to commit SEA under the protection of the UN flag.

\section{Immunity of Peacekeepers}

Peacekeepers operate under the leadership and authority of the UN, which grants them immunity from the jurisdiction of host states under the Convention on the Privileges and Immunities of United Nations 1946 (Articles 18 and 22) and Convention on the Safety of the UN and Associated Personnel 1994 (Article 1(i)). According to these Conventions, peacekeepers deployed by the Secretary-General are "UN personnel" and enjoy immunity from the jurisdiction of host states, which exempts peacekeepers from any legal action. This immunity is functional, not absolute, in that it protects peacekeepers for their "official acts" performed according to their mission mandate and does not extend to the acts beyond their official functions. This functional immunity is necessary to protect physical security and operations from local interference so that the mission objective is not prejudiced.
However, the functional immunity in its strict sense has dissipated as its distinction with full or absolute immunity is now blurred. Peacekeeping missions follow a broad and allencompassing understanding of their official functions. The limited protection under the "functional immunity" has become absolute immunity, which inclusively includes any unlawful acts even when such actions are beyond the mandate and/or against the very objective of the peacekeeping mission. All host states are obliged to protect all UN personnel deployed in their territories even in the commission of crimes by UN personnel (1994 Convention Article 7). The offending personnel cannot be prosecuted in host states without the Secretary-General's immunity (1946 Convention Article 20). This immunity structure creates jurisdictional gaps in the accountability and liability of peacekeepers, which leads them to enjoy total impunity. Its existence influences the decision of some peacekeepers to commit SEA against civilians in host states with impunity. This position underscores the necessity of waiving the offending peacekeepers' immunity to end impunity and face the full force of law like any crime.

In response to the growing incidents of SEA by peacekeepers, the Secretary-General has waived immunity in only a few isolated cases, such as in 2002 he waived the immunity for committing SEA against girls in East Timor, and the offenders were prosecuted under the jurisdiction of East Timor (Rawski, 2002; Voetelink, 2013). But he has ignored to waive immunity in a large number of SEA incidents committed by peacekeepers, who went unpunished. This inconsistency in waiving the immunity may be attributable to the fact that there are no set criteria to follow exactly when and in which circumstances the Secretary-General must waive the immunity. This discretion, if not anomaly, appears to be suffering from a lack of specificity, which exposes a legal loophole for the defense to conveniently rely on in pleading for total exoneration and/or a reduced sentence for the perpetrators. Thus, the immunity of peacekeepers serves as a shield and sword for the lawbreaking peacekeepers.

\section{Mechanisms to Prosecute Peacekeepers for SEA}

Theoretically, the peacekeepers who commit crimes during peacekeeping operations are generally subject to the laws of the UN, host states, and home states (Ladley, 2005). In reality, though, the issue of accountability for crimes committed by peacekeepers and how their immunity affects jurisdiction is complicated. According to MOU, when peacekeeping personnel commits crimes, they are under the jurisdiction of their home states (United Nations, 2007). If peacekeeping forces function under the authority and control of the 
UN, why cannot the Organisation assume responsibility for and jurisdiction over its peacekeepers' criminal acts? The existing jurisdictional arrangements to hold peacekeepers accountable for SEA are dysfunctional and discriminatory, and their exercise of jurisdiction over the offending peacekeepers has been too parochial to be effective, as explained below.

\section{Jurisdiction of Home States}

Troop-contributing home states are responsible for investigating alleged misconducts by their military personnel under the MOU of 2007 (Simm, 2011). This jurisdiction over peacekeeping personnel is predicated because they are subject to their home states' national law, where their immunity is inoperative. The exercise of home states' jurisdiction is riddled with procedural complexities. A home state may initiate an investigation and send officials to identify the alleged misconduct and its perpetrator/s in host states, which must immediately notify the UN (United Nations, 2007). This investigation in a foreign state can lead to diplomatic hurdles (Gallmetzer, 2010). The investigative process often encounters practical problems of resource constraints, which may undermine translation and interpretation services, evidence gathering and preservation, and most importantly, active cooperation from host states.

A home state's investigator wanting to interview witnesses or meet the rape victims in a host state may be problematic due to the social stigma and shame prevalent in the victims' community. According to an HRW report, when peacekeepers in Somalia committed SEA, only "2 out of the 21 women and girls interviewed by HRW had filed a complaint with Somali or other authorities" (Bader \& Muscati, 2014). The other victims did not complain, fearing social stigma associated with being raped and the offending peacekeepers choosing not to protect them from insurgent groups' attacks (Sen \& Farmer, 2004). Given that the victims are in host states, the investigation must be held there, which could be dangerous for the investigator/s because host states are invariably not stable, and the examination may be in a conflict area with insurgent groups. The presence of the AlShabaab insurgent group in Somalia was the main reason that prevented the home state investigators from contacting the civilian victims (Bader \& Muscati, 2014).

Apart from the above difficulties, there is no guarantee that home states will prosecute its offending peacekeepers even when the allegations are substantiated. This is because not all home states have jurisdiction over crimes committed by their citizens in foreign jurisdictions, and when their peacekeepers serve under the UN authorization, home states can- not hold them accountable (Voetelink, 2013). The US civilian personnel working as peacekeepers in Somalia, Haiti, and the Balkans committing SEA went unpunished in the US because its law covers only crimes committed by civilian personnel working with military forces, not the crimes of civilians working as staff on an international mission (Ladley, 2005).

The jurisdiction of home states is largely theoretical as its application seldom happens, and substantiated allegations often go unaccountable. Though there are instances of home states prosecuting their offending peacekeepers, such instances of criminal prosecution are rare. Even in those home states where domestic jurisdiction is exercised over the alleged commission of crimes while serving in peacekeeping missions, investigations are conducted internally with the usual punishment is disciplining (suspension, demotion, repatriation, and termination). This policy of allowing home states to act as a judge of their cause has resulted in the lackluster enforcement of home states' jurisdiction. In the UN's evaluation, troop-contributing states' investigations are unreliable and delayed due to their perceived conflict of interest, which has weakened enforcement actions (Human Right Watch, 2016; OIOS, 2015). The alarmingly low efforts in home states have not been very successful due to prosecutorial discretion, falling far short of what is required to combat these crimes effectively. Consequently, the impunity of the perpetrators prevails over justice to the victims.

\section{Jurisdiction of Host States}

Under its territorial sovereignty, a state has jurisdiction over any person who enters its territory, and if it breaks its law, they are subject to the local court's jurisdiction. However, an exception has been made for UN peacekeepers by conferring immunity, which exempts peacekeepers from the jurisdiction of host states even when they commit serious crimes. The General Assembly in 2007 provided that in cases of misconduct during peacekeeping missions, host states cannot prosecute peacekeepers because of their immunity (UN. General Assembly, 1990; United Nations, 2007).

This immunity is the real effective limitation on the jurisdiction of host states over peacekeepers. There is an apprehension that if host states prosecute peacekeepers, their home states will be reluctant or even refuse to contribute to peacekeeping missions. The legal systems of host states are different with dissimilar judicial bodies, investigative process, judicial integrity, and corrective service, which create uncertainty concerning the treatment of offending peace- 
keepers in host states. Most UN peacekeeping missions are deployed in conditions that may not have functioning governments (Somalia Report, 1998) and/or a suitable judicial system to adjudicate and punish crimes. Even where peacekeepers are deployed in stable states (non-conflict areas), their immunity prevents host states from prosecuting them for any crime they commit (Wills, 2013). The jurisdictional bar on host states caused by the immunity of peacekeepers effectively affords impunity for criminal acts in the territory of aggrieved host states, which suffer actionable injury without any right to redress.

\section{Jurisdiction of the UN Secretary-General}

The UN General Assembly established a committee of legal experts to ensure the legal accountability of peacekeepers. The committee recommended that host states exercise jurisdiction over crimes committed by peacekeepers and that such local jurisdiction would be important in obtaining access to witnesses and facts surrounding crimes. Instead of establishing this legal accountability of peacekeepers, the UN has opted for administrative measures, including the "naming and shaming" of those home states that do not prosecute SEA allegations and fail their accountability obligations.

The UN Security Council has empowered the SecretaryGeneral to repatriate peacekeeping units "when there is credible evidence of widespread or systemic SEA by that unit" (para. 1) from those host states where the allegations have arisen. This does not mean that the Secretary-General waives immunity in these cases, and when he exercises his authority to repatriate units, the peacekeepers concerned remain under immunity and are still subject only to the jurisdiction of their home states, not host states. This Security Council measure preserves the status quo of the political and legal mindset of the UN and its members that has historically undermined the creation of a legal accountability regime for peacekeepers. Consequently, its measures falling short of any legal action have failed to produce its intended outcome as peacekeepers continue to commit SEA with impunity.

The Secretary-General is the sole authority to waive the immunity of peacekeepers in cases where he deems that the protection emanating from immunity perverts the course of justice and that such a waiver would not be prejudicial to the interest of the UN (Defeis, 2008). The consequence of waiving immunity is the resumption of the jurisdiction of host states, which can investigate, prosecute, and punish the offending peacekeepers. The UN does not seem to favour the application of host states' jurisdiction on its peacekeep- ers. As a result, the immunity waiving authority has become largely theoretical. In practice, the exemption of peacekeepers is considered unconditional and necessary for their rights and security, a foremost concern of the UN that prevails over justice to the victims of SEA.

\section{Waiving the Immunity to Break Impunity for Criminal- ity}

The issue of SEA by peacekeepers in the peacekeeping missions is a heinous crime perpetrated on vulnerable women and girls, including underaged, in host states, and the UN efforts to combat it has been ongoing for decades. Despite multiple UN measures, SEA is perpetrated during mission after mission, and the reason is largely attributable to its non-penal measures having no meaningful deterrent effects. These successive failures call for the introduction of a strict legal accountability regime. It is high time for the UN to grapple with this reality after decades of indifference to such an actionable remedy.

The first step that must be revisited is the immunity to alleged peacekeeping criminals and the conditions of waiving it. It is difficult to fathom how the rights and security of peacekeeping perpetrators override the rights and security of victims. The UN must come out of this unjust protection, meant for only the "official functions" of peacekeepers. The UN measures are not predicated on the fundamental crime prevention principle that criminal acts preempt criminal responsibility to be punished with appropriate punitive sanctions. By permitting too much latitude in punishing the offending peacekeepers, the UN measures have created a real perception that committing crimes under the immunity would entail no criminal responsibility for the perpetrators. Thus far, immunity has become a perversion that creates impunity, encouraging criminal behavior by removing the fear of predictable penal sanctions. Given the ineffectiveness of UN non-legal measures, the immunity waiving option of the Secretary-General is in order and indeed imperative for the prevention of SEA in the UN peacekeeping missions.

Can the immunity of peacekeepers be a defense against the commission of SEA or gross violations of human rights and IHL? Let us see what the current status of sovereign immunity of heads of the state/government is. It shows that their immunity affords no protection to those heads of the state/government who committed persecution and violations of the human rights of their civilians. Gross human rights abuses in Chile under General Pinochet in 1973-90 led the UN Ad Hoc Working Group on Chile to recommend his prosecution for crimes against humanity in 1976 (AI Re- 
port, 1999). Pinochet faced the Chilean court despite his life-long immunity granted by the Chilean Senate but died on trial. The prosecution and/or punishment of former heads of the state/government, notably Slobodan Milošević of Serbia, Charles Taylor of Liberia, Lauren Gbagbo of Ivory Coast, Bosnian wartime Serb President Radovan Karadžić, Chadian dictator Hissene Habre, Guatemalan military ruler General Efrain Rios Montt, Bashir al-Assad of Sudan, Muammar Gaddafi of Libya, Rwandan Prime Minister Jean Kambanda, and Congolese Vice-President Jean-Pierre Bemba Gombo, are a watershed development in the erosion of sovereign immunity in cases of gross human rights transgressions.

The trials of heads of these states/governments are a deep inroad into their aura of invincibility and impunity from prosecution under their sovereign immunity and set a precedent that even leaders of the state/governments responsible for gross violations of human rights are not immune from criminal responsibility and justice before courts/tribunals. It is the imperativeness of criminal sanction that is very much the lynchpin of these trials. It is recognized that SEA against women and girls by peacekeepers is a grave violation of the human rights and dignity of the civilian victims in host states (MONUC, 2004). Protecting these sexual predators under the guise of UN immunity contradicts its own crime prevention pursuits in its peacekeeping missions. It amounts to defending indefensible, which undermines the shared aspiration and resolve of the international community to safeguard civilians for dignified human existence. The immunity of peacekeepers is not for their benefit and to condone impunity for their crimes. These criminal acts fall squarely outside their "official functions" and objectives of peacekeeping missions, and the immunity cannot be a legitimate defense against SEA. Hence, waiving their immunity ensures fairness, justice, and credibility of the UN peacekeeping missions.

The waiver of immunity would resuscitate the jurisdiction of host states. This should be the normal course of legal action for the simple reason that the place of the commission of SEA and the presence of the perpetrators, victims, and witnesses are within the territory of host states. The immunity of peacekeepers has artificially interrupted this normal due process of law, which warrants to be restored with appropriate checks and balances to guard against unfair prosecution. The UN Basic Principles and Guidelines on the Right to a Remedy and Reparation for Victims of Gross Violations of International Human Rights Law and Serious Violations of IHL 2005 maintains that states have a positive duty to investigate and prosecute gross violations of human rights, including sexual violence.

The principal crimes of which peacekeepers have been accused are crimes against women in host states. The Security Council focused on protecting women during armed conflicts to avoid crimes against them by conflicting parties. This UN protection policy provides a double standard that treats conflicting parties' criminals and their crimes against women as more equal than UN peacekeeping protectors. The UN is an international legal person with rights and duties under international law (Freedman, 2018), which incurs responsibility should it fail to fulfill its obligations. The UN deploys peacekeepers, determines their mandates, directly controls their operations, provides immunity for their "official functions" and cannot shrug off its vicarious responsibility for peacekeepers' SEA. No stretch of legal persuasion can justify the impunity of the offending peacekeepers for SEA, a hardcore atrocity crime and gross violation of human rights, under the protective garb of their functional immunity.

The referral for the prosecution to home states of the offending peacekeepers has been riddled with noncompliance. The qualms about the fair trial in host states may be overcome by the UN being involved in the trial process in host states' court/tribunal. The UN may even establish a hybrid special court/tribunal in host states with jurisdiction over the offending peacekeepers. The Special Criminal Court in CAR, established in 2015 with the support of the UN and EU, is an example though its jurisdiction is discriminatory and limited to human rights abuses by only local rival armed groups, not by peacekeepers. The UN can establish a special criminal court/tribunal in host states with jurisdiction over the offending peacekeepers. A mixed special criminal court/tribunal is likely to be rewarding in ensuring a fair trial, thorough investigation, safe evidence procurement, preservation, and cost-effective and time-efficient prosecution in host states.

\section{CONCLUSION}

The recent incident of sexual act inside a UN vehicle in Israel is an integral part of a deeply entrenched culture of commission of SEA by peacekeepers in missions with impunity emanating from their immunity. Multiple non-penal sanctions have not succeeded in preventing this chronic cancer in the UN peacekeeping missions. The perceived possibility of unfair or biased trials in host states has led the UN to preclude the local jurisdiction. But its reliance on home states' jurisdiction for accountability is often flouted. The UN has not addressed this problem of MOU, which has no legally binding effect, and its compliance is based on the goodwill of 
home states. Nor has the UN renegotiated and revised MOU to monitor the responsibility of home states to bring their offending peacekeepers to justice. Even if MOU is modified, it is unlikely to succeed due to the inherent self-interest and legal limitation of home states.

The ambivalence of the UN about the gravity of the crimes of peacekeepers and the right of aggrieved host states are discernible. It is this jerry meandering approach to fight against SEA that is partly responsible for limited success. It is not good enough for the UN to make reactive rhetorical promises after every media report of an incident of SEA that solicits firm action. It is high time for the UN to take responsibility for its peacekeepers and commanders operating under its direct authority and control and stop passing it to peacekeepers contributing states. This suggests that the UN should discontinue its social curative measures as a reformative pursuit. Its victim assistance and rehabilitation scheme should be improved by allocating sufficient funds to be distributed expeditiously and free from bureaucratic inefficiency and delay. In addition to these "soft" curative measures, the UN must consider "hard" punitive measures in the form of criminal conviction and incarceration as a preventive approach by bringing its wrongdoing peacekeepers to justice. Repeating the same non-carceral procedure after decades of application can no longer be the only answer to the challenge.

Criminal sanctions must be proportional to the gravity of the crime. SEA is a hardcore crime that gives rise to criminal responsibility and prosecution, not impunity. This wellestablished legal position of the offense needs to be recognized, leaving no palatable option for the UN other than introducing and enforcing criminal action against the offending peacekeepers and their commanders. The proactive consideration of a corrective penal step to convey a message that the immunity does not protect and condone its peacekeepers committing SEA has assumed and will continue to assume paramount importance for the credible management of UN peacekeeping missions. Should such a legal accountability regime be enforced strictly, it would likely be a watershed in the UN fight against SEA under its flag and make a dent in peacekeepers' predatory behavior to become the protectors of vulnerable civilians in mission states. Otherwise, its existing peripheral approach to the prevention of the perineal crisis of SEA in the UN peacekeeping missions is likely to remain as elusive as ever.

\section{Limitations of the Research}

This article limits its scope to a critical examination of the responsibility of the UN peacekeepers and their accountability when they commit only sexual misconduct and sexual violence against women in host states. It does not deal with other crimes committed in host states, such as smuggling, killing, and any other atrocity crimes committed by UN peacekeepers against the civilians in host states. Nor does it deal with the command structure of the UN peacekeeping mission and its system of reporting of the commission of crimes by peacekeepers. Being non-empirical research, no independent factual investigation or collection of statistical data has been undertaken. All statistical data used in this article has been drawn from publicly available primary and secondary sources with their due acknowledgments.

\section{Scope of Future/Further Research}

So far, up until 2021, the UN peacekeeping forces have been engaged in $71 \mathrm{UN}$ peacekeeping missions. In these missions, the UN peacekeepers have performed their mandated duties of protecting civilians and promoting human rights. In many instances, however, the UN peacekeepers have gone beyond their required assignment to engage in numerous crimes against the civilians in host states. Further studies need to be focussing on the command structure of the UN peacekeeping forces to render it more effective and accountable and its system of reporting of the commission of crimes by peacekeepers and an opportunity for the victims to report and lodge a complaint of any sexual misconduct by peacekeepers. Although the jurisdictional issue has briefly been dealt with in this article to show the strengths and weaknesses of the available options, there is room for independent and extensive research to determine the most appropriate jurisdiction in which the offending peacekeepers could be prosecuted and punished - a puzzling matter that remains to be resolved.

\section{REFERENCES}

AI Report. (1999). The Pinochet case - Universal jurisdiction and absence of immunity for crimes against humanity. Retrieved from https://bit.1y/3kbMDg4

Al-Jazeera. (2016). 'Sickening' sex abuse alleged in CAR by UN peacekeepers. Retrieved from https://bit. 1y/304Sw7q

Alston, P. (2009). Press statement by Professor Philip Alston, UN Special Rapporteur on extrajudicial executions. Mission to the Democratic Republic of the Congo, 5-15 October 2009. Retrieved from https://bit. ly/3H3iyck

Amnesty International. (2011). UN aids sudanese official wanted for war crimes. Retrieved from https ://bit. ly/3ERvLmI 
Bader, L., \& Muscati, S. (2014). The power these men have over us: Sexual exploitation and abuse by African Union forces in Somalia. Retrieved from https://bit.1y/3mV1FeC

Burke, R. S. (2014). Sexual exploitation and abuse by UN military contingents: Moving beyond the current status quo and responsibility under international law. Leyden, The Netherlands: Martinus Nijhoff Publishers.

Defeis, E. F. (2008). Un peacekeepers and sexual abuse and exploitation: An end to impunity. Washington University Global Studies Law Review, 7, 185-214.

Deschamps, M., Jallow, H. B., \& Sooka, Y. (2015). Report of an independent review on sexual exploitation and abuse by international peacekeeping forces in the Central African Republic (Tech. Rep.). New York, NY: UN DPKO.

Freedman, R. (2018). Unaccountable: A new approach to peacekeepers and sexual abuse. European Journal of International Law, 29(3), 961-985. doi:https://doi.org/10.1093/ejil/chy039

Gallmetzer, R. (2010). Prosecuting persons doing business with armed groups in conflict areas: The strategy of the office of the prosecutor of the international criminal court. Journal of International Criminal Justice, 8(3), 947-956. doi: https://doi.org/10.1093/jicj/mqq037

Heintze, H.-J. (2011). Convergence between human rights law and international humanitarian law and the consequences for the implementation. In Hans-Joachim Heintze and Andrej Zwitter (Ed.), International law and humanitarian assistance. Berlin, Germany: Springer. doi:https://doi.org/10.1007/978-3-642-16455-2_6

Holt, K., \& Hughes., S. (2007). UN staff accused of raping children in Sudan. Retrieved from https: //bit. ly/3ob675C Human Right Watch. (2016). Central African republic: Rape by peacekeepers. Retrieved from https://bit. 1y/3CX823V Human Right Watch. (2017). Central African republic: Civilians targeted in war. Retrieved from https://bit. ly/3CUdEv0 Jerusalem Post. (2007). UN staffers allegedly committed rape in Sudan. Retrieved from https://bit. Iy/3C1eVAc

Ladley, A. (2005). Peacekeeper abuse, immunity and impunity: The need for effective criminal and civil accountability on international peace operations. Politics and Ethics Review, 1(1), 81-90. doi:https://doi.org/10.1177/ 1743453 X0500100108

LCB v UK. Application/Case no. 14/1997/798/100. (1998).

Mahmut Kaya v Turkey. Application/Case no. 22535/93. (2000).

Maus, S. (2011). Human rights in UN peacekeeping missions: A framework for humanitarian obligations? In H.-J. Heintze \& A. Zwitter (Eds.), International law and humanitarian assistance. Berlin, Germany: Springer.

MONUC. (2004). MONUC: A case for peacekeeping reform (Tech. Rep.). Retrieved from https://bit. ly/3qg1sC9

Murphy, R. (2006). An assessment of UN efforts to address sexual misconduct by peacekeeping personnel. International Peacekeeping, 13(4), 531-546. doi:https://doi.org/10.1080/13533310600988820

Nicaragua v US. Military and Paramilitary Activities in and Against Nicaragua. (1986).

OIOS. (2005). Investigation by the office of internal oversight services into allegations of sexual exploitation and abuse in the United Nations organization mission in the democratic republic of the Congo (UN Doc. A/59/661). New York, NY: United Nations. Retrieved from https://bit.1y/3bQbZvn

OIOS. (2014). Evaluation of the implementation and results of protection of civilians mandates in UN peacekeeping operations (UN Doc A/68/787). New York, NY: United Nations. Retrieved from https://bit. ly/3bQbZvn

OIOS. (2015). Un office of international oversight services, evaluation report of the enforcement and remedial assistance efforts for sexual exploitation and abuse by the UN and related personnel in peacekeeping operations (Tech. Rep.). New York, NY: United Nations. Retrieved from https://bit.1y/3mTxWjD

Osman v UK. Application/Case no. 23452/94, European Court of Human Rights, Judgment of October 28. (1998).

Rawski, F. (2002). To waive or not to waive: Immunity and accountability in UN peacekeeping operations. Connecticut Journal of International Law, 18, 102-132.

Sen, A., \& Farmer, P. (2004). Pathologies of power: Health, human rights, and the new war on the poor. Retrieved from https://bit.ly/301ffly

Simm, G. (2011). International law as a regulatory framework for sexual crimes committed by peacekeepers. Journal of Conflict \& Security Law, 16(3), 473-506. doi:https://doi.org/10.1093/jcsl/krr019

Somalia Report. (1998). Report of the independent expert on the situation of human rights in Somalia (UN Doc. E/CN.4/1998/96). New York, NY: United Nations. 
Special Measures. (2020). For protection from sexual exploitation and abuse (UN Doc. A/74/705). New York, NY: United Nations.

Thakur, R. C., Aoi, C., \& De Coning, C. (2007). Unintended consequences of peacekeeping operations. Tokyo, Japan: United Nations University Press.

UK v Albania. Corfu Channel Case, International Court of Justice Reports. (1949).

UN Field Mission Conduct. (2020). Conduct in UN field missions, number of SEA allegations reported by year. Retrieved from https://bit.1y/31Hy0Ld

UN. General Assembly. (1990). Comprehensive review of the whole question of peace-keeping operations in all their aspects: Resolution/adopted by the General Assembly. (UN Doc. A/45/594). New York, NY: United Nations. Retrieved from https://bit.1y/301KgFi

UN General Assembly. (2002). Investigation into sexual exploitation of refugees by aid workers in West Africa (UN Doc. A/RES/57/306). New York, NY: United Nations.

United Nations. (1999). Secretary-General's Bulletin - Observance by United Nations forces of international humanitarian law. Retrieved from https://bit.1y/3HOPPVv

United Nations. (2000). Report of the panel on the un peace operations. Retrieved from https://bit.1y/3qfglVi

United Nations. (2007). Report of the special committee on peacekeeping operations and its working group on the 2007 resumed session. Retrieved from https://bit.1y/3bQlzhT

United Nations. (2017). List of peacekeeping operations. Retrieved from https : //bit.1y/3bV44Ne

Voetelink, J. (2013). Status of forces and criminal jurisdiction. Netherlands International Law Review, 60(2), 231-250. doi:https://doi.org/10.1017/S0165070X12001179

Wheeler, S. (2020). UN peacekeeping has a sexual abuse problem. Retrieved from https://bit. Iy/3bLUAUJ

Willmot, H., \& Sheeran, S. (2013). The protection of civilians mandate in UN peacekeeping operations: reconciling protection concepts and practices. International Review of the Red Cross, 95, 517-538. doi:https://doi.org/10.1017/ S1816383114000095

Wills, S. (2009). Protecting civilians: The obligations of peacekeepers. Oxford, UK: Oxford University Press.

Wills, S. (2013). Continuing impunity of peacekeepers: The need for a convention. Journal of International Humanitarian Legal Studies, 4(1), 47-80. 